\title{
Accounting Editorial Board Membership And Research Output
}

Homer L. Bates, University of North Florida, USA

Bobby E. Waldrup, University of North Florida, USA

Vincent J. Shea, St. John's University, USA

Whitney L. Heflin, University of North Florida, USA

\begin{abstract}
The primary purpose of this article is to examine whether the university affiliation of faculty members on the editorial boards of three top academic accounting journals is related to the university affiliation of the faculty that publish in these journals. The journals selected - The Accounting Review (AR); The Journal of Accounting Research (JAR); and, Accounting, Organizations and Society (AOS), were identified by Chan, et al. (2009) as the top three accounting research journals. The board members (as of January 1, 2007) of these three journals were categorized by university affiliation (both current employer and doctoral-degree granting), and cross referenced with the authors (including co-authors) of all main articles published in these three journals during the calendar years of 2007-2009. The results indicate that the majority of the authors at JAR and AOS had academic affiliations different from the editorial board members. In the AR, however, over $60 \%$ of the authors had the same academic affiliations as the 101 members of the AR editorial review board. Secondary results provide that a small handful of university affiliations dominate the U.S.-based journal boards, however this connection was not as strong in the non-U.S. AOS. Overall, less than 11\% of AACSB accredited business programs are represented on these collective boards, although AACSB accounting specific accreditation does increase this ratio to a $14 \%$ representation.
\end{abstract}

Keywords: Research; Editorial Boards; Accounting; Universities

\section{INTRODUCTION}

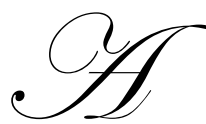

cademics are expected to conduct research and publish the results of their research in academic journals. The top researchers are identified as those who regularly publish in high quality journals. Therefore, the quality of the published research is defined by the quality of the journal in which it appears, and not necessarily by the quality of the research itself. Journals can be rated by subjective and/or objective means. A subjective measure of journal quality is to ask researchers, along with department chairs, deans, and perhaps, practitioners to rank the journals in their field. An objective measure would be to use citations or faculty editorial board membership as a measure of quality. The more often a journal is cited or the greater the number of faculty board members from highly-rated accounting programs, the higher would be journal's rating.

Faculty members' annual evaluations are based, in part, in their publications in highly-rated journals. Promotion and tenure decisions are also partially based on publications in these journals. Salary increases, teaching loads, research funding, summer support and research awards are also based on publications in top journals (Swanson, 2004). The editors of the Journal of Accounting and Economics have calculated that an article published in their journal was worth $\$ 30,000$ in lifetime income to the author (Jönsson, 2006). Departments, colleges and universities are also ranked by the number of publications by their faculty in top-rated journals. Publication in the top research journals is extremely difficult since the acceptance rate hovers around 10\% (Moizer, 2009, p. 286).

Moizer (2009) states that journal publication is a game that is played by four parties; the author, the reviewers, the editor and bureaucrats that argue that quality researchers publish in quality journals. The primary 
purpose of this descriptive article is to examine the university affiliations of the reviewers in the publication game process. The members of the editorial review board of three top-rated accounting journals were identified at the beginning of 2007 along with their home universities and their doctoral-degree granting universities. The authors and co-authors of all main articles published in the three journals during 2007, 2008 and 2009 were identified along with their home universities. The relationship between the editorial board members' university affiliations and the affiliations of the authors were examined and discussed.

\section{BACKGROUND}

There is a paucity of published research on editorial boards of U.S. accounting journals. Mittermaier (1991) examined the editorial boards of 13 accounting journals and determined that a small number of schools dominated the editorial boards. She also found that the higher rated the journal, the fewer number of schools dominated the editorial review board. Lee (1997) studied the editorial boards of six accounting journals and found that a relatively small number of universities dominated the boards of The Accounting Review, Journal of Accounting Research and Journal of Accounting and Economics. He also found that Accounting, Organizations and Society was not dominated by a select group of universities.

Williams and Rodgers (1995) looked solely at the editorial board of The Accounting Review. Their results indicated that substantial power is held by graduates of 15 doctoral-granting universities. They concluded that selection to the editorial review board is not unbiased. Moizer (2009) examined all four parties in the publication game. With regards to reviewers, he initially questioned their motivation since reviewing is usually unpaid and can be very time-consuming. He stated a possible reason for volunteering as a reviewer was the positive reputation and network gained from being a reviewer. He finally argued reviewers may gain an economic benefit citing Hamermesh (1994) who concluded, nearly one-third of the reviewers had recently published in the journal and others had articles under review or forthcoming. Brinn and Jones (2007) examined the perceptions of editorial review board members of accounting journals. A questionnaire was sent to 700 randomly selected review board members of 56 accounting journals - 159 responses were received, a response rate of $22.7 \%$. Some of their major findings were board members believed appointments to boards should be made on the basis of publication records and research reputation. They also found a belief that reviewers should be unbiased, but it was acceptable to know the identity of the manuscript's author. Finally, they found board members disapproved of institutional or group dominance of journal review board membership and had mixed views regarding the forced engineering of board membership to include women or racial minorities.

The editorial boards of journals in non-accounting disciplines have been examined in various ways. Hardin, et al. (2008) examined the research productivity of board members of the top five academic finance journals and concluded; "Selection to any of the five journals' editorial board requires substantial research achievement" (2008, p.238). Chan, Fung and Lai (2004) used four-year data to rank international business programs based on membership on editorial boards of 30 international business journals. Based on these criteria, Michigan State University, New York University and Columbia University were the top rated international business programs. Weinrach, et al. (2006) examined the research productivity of the editorial board members of three American counseling and counseling psychology journals. They found the research productivity of the board members varied substantially at the three journals. They conjectured this because of the different missions and clientele of the three journals. Nisonger (2002) reported on three measures of international composition of board members of 153 business, political science, and genetics journals. He found the international board composition was much higher in genetics than in business or political science.

\section{METHODOLOGY}

The first issue of each of the three journals in 2007 was selected as the base for determining the members of the editorial review board. The January 2007 issue of The Accounting Review (AR) was used to determine the 101 editorial review board members; the March 2007 issue of the Journal of Accounting Research (JAR) was used to determine its 36 board members and the January/February 2007 issue of Accounting, Organizations and Society $(A O S)$ was used to determine its 47 editorial review board members. The university affiliation and the doctoraldegree-granting information were determined by examining the appropriate issue of the journal, Hasselback's 
Accounting Directory (2007) or, if necessary, conducting a Google search. The university information for all 184 editorial review board members was obtained in this manner.

The 101 editorial review board members of $A R$ were affiliated with 49 different universities and were from 37 different doctoral-granting universities. The members of the JAR's editorial review board were affiliated with 24 different home universities and possessed doctoral degrees from 17 different universities. AOS's members were affiliated with 34 different universities and had doctoral degrees from 30 different universities. The authors and coauthors of all main articles in all issues of the three journals for 2007 through 2009 were determined.

\section{RESULTS}

AR published 17 issues and 164 articles by 375 authors and co-authors during the period. The JAR published 15 issues with 105 articles by 154 authors and co-authors. AOS published 16 issues and 128 main articles by 244 authors and co-authors. The data is summarized in Table I

\begin{tabular}{|c|c|c|c|c|c|c|}
\hline & & & & Table 1 & & \\
\hline & & & Sumr & nmary Data & & \\
\hline & & Januar & ry 1,2007 & 7 - December 31, 200 & & \\
\hline & & & & & Accounting Organizations & \\
\hline & & The Accounting & The Jour & urnal of Accounting & & \\
\hline & & Review & Researcl & & and Society & Total \\
\hline Number of Editori & & & & & & \\
\hline Review Board M & embers & 101 & & 36 & 47 & 184 \\
\hline Number of Differe & & & & & & \\
\hline Home Universitie & es of & & & & & \\
\hline Review Board M & embers & 49 & & 24 & 34 & 79 \\
\hline Number of Univers & sities & & & & & \\
\hline with 2 or more $\mathrm{Re}$ & eview & & & & & \\
\hline Board Members & & 29 & & 7 & 12 & 48 \\
\hline & & & & & & \\
\hline Number of Differe & & & & & & \\
\hline Doctoral-Grantin & & & & & & \\
\hline Universities of $\mathrm{R}$ & eview & & & & & \\
\hline Board Members & & 37 & & 17 & 30 & 59 \\
\hline & & & & & & \\
\hline $\begin{array}{l}\text { Number of Doctor } \\
\text { Granting Univers }\end{array}$ & $\begin{array}{l}\text { al- } \\
\text { ities with }\end{array}$ & & & & & \\
\hline 2 or more Reviev & w Board- & & & & & \\
\hline Members & & 20 & & 7 & 12 & 39 \\
\hline & & & & & & \\
\hline Number of Issues & & & & & & \\
\hline Published & & 17 & & 15 & 16 & 48 \\
\hline Number of Main A & rticles & & & & & \\
\hline Published & & 164 & & 105 & 128 & 397 \\
\hline Number of Authors & & & & & & \\
\hline Co-authors & & 375 & & 154 & 244 & 773 \\
\hline & & & & & & \\
\hline Number of Articles & 5 published & & & & & \\
\hline by Review Board & Members & 47 & & 29 & 29 & 105 \\
\hline (Percent of Total & Main Articles) & $29 \%$ & & $28 \%$ & $23 \%$ & $26 \%$ \\
\hline
\end{tabular}




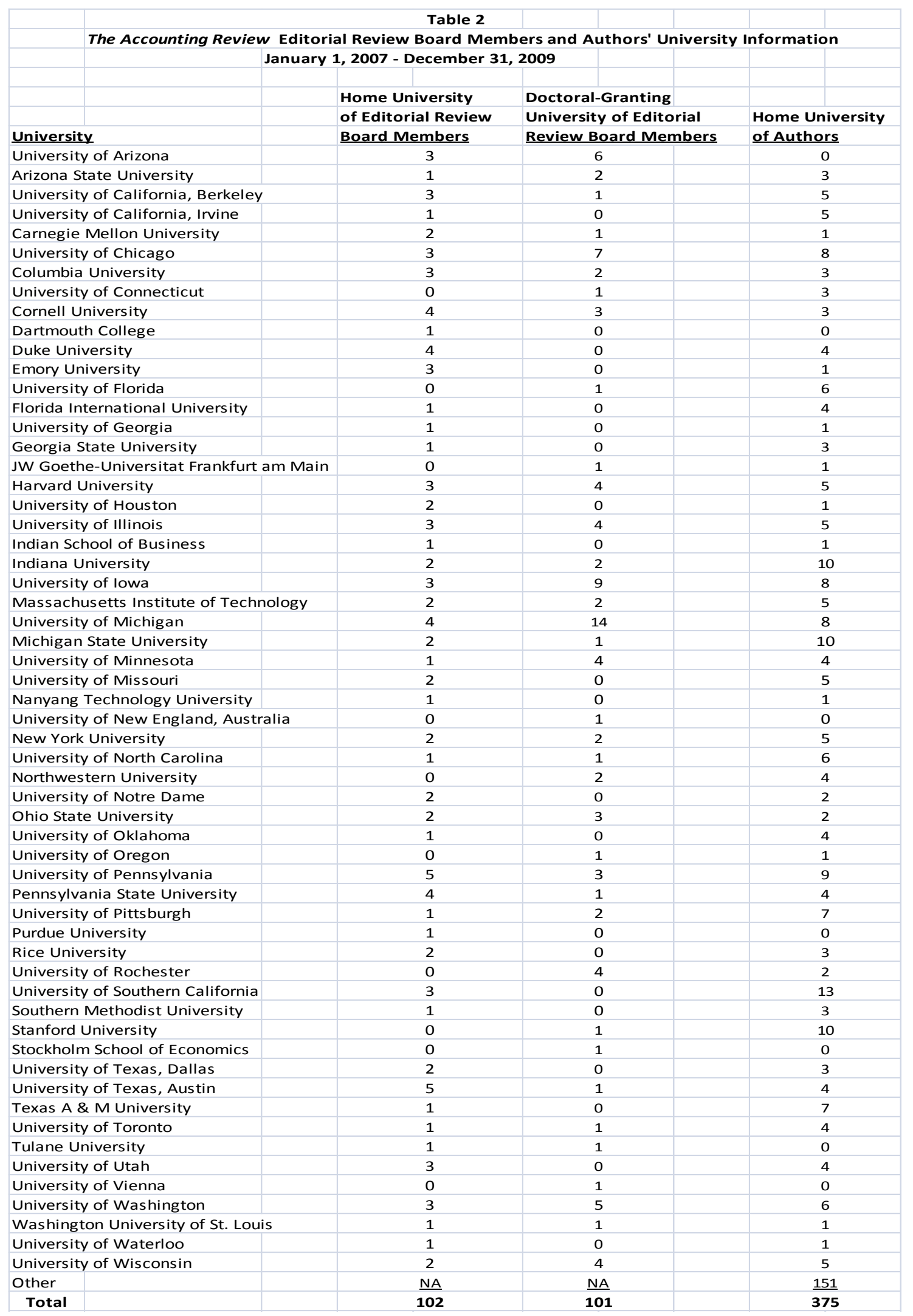




\section{The Accounting Review}

The results for $A R$ are shown in Table 2. Of the 375 authors or co-authors, 224 or nearly $60 \%$ were at universities that had an affiliation with an editorial board member. As shown in Table 1, 47 articles were authored or coauthored by members of the Editorial Review Board. This is 29 percent of the total articles published. As previously shown by Mittermaier (1991), a small number of universities dominated the author list. Thirteen universities accounted for 29 percent of the authors. There appears to be a strong relationship between the university affiliation of the editorial review board members and authorship in the journal. It is also of interest to note that U.S. universities dominate the editorial review board affiliation. Only four of the 101 board members were at foreign universities and five board members received their doctorates at foreign universities.

Table 3

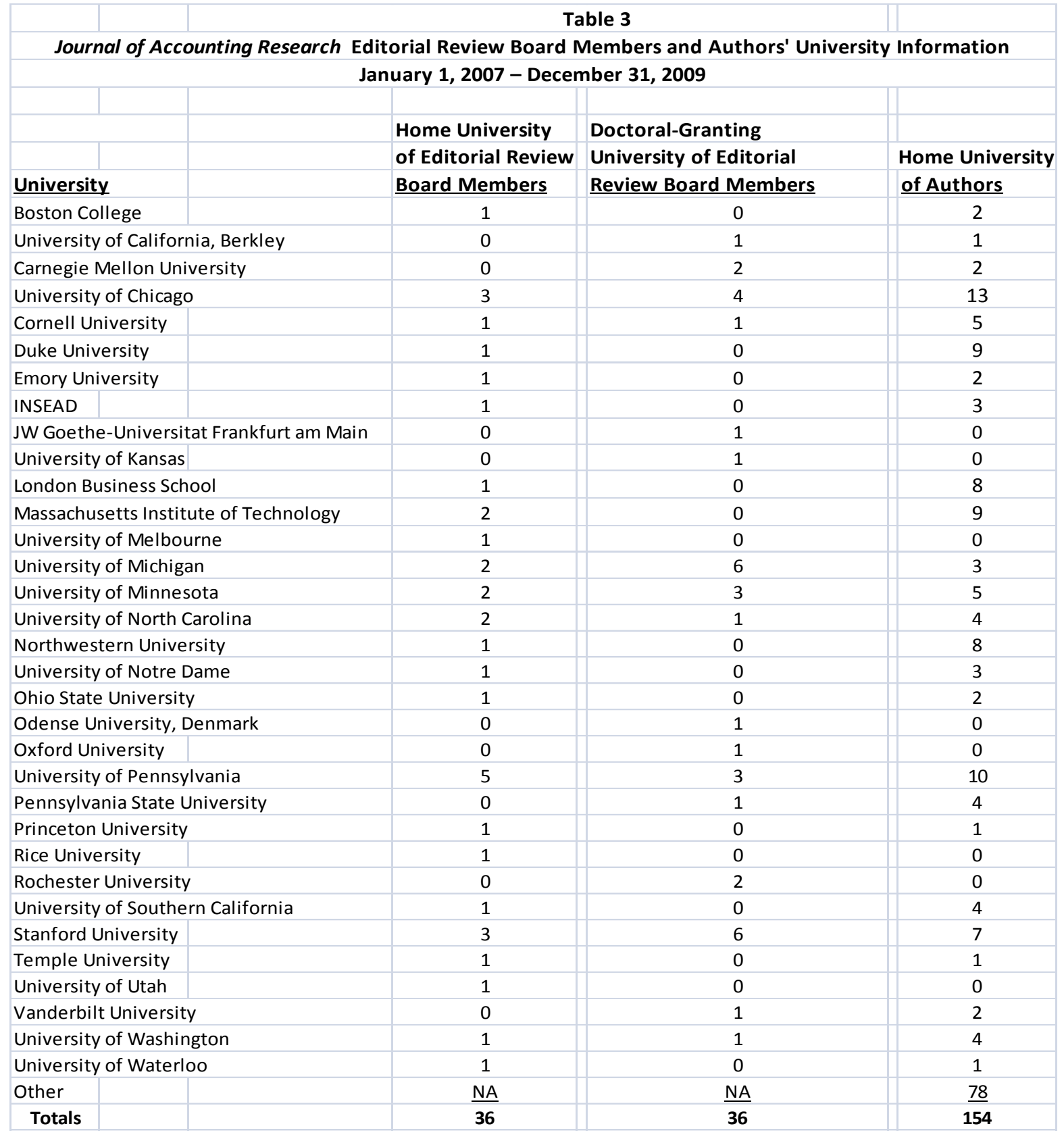


Table 4

Accounting, Organizations and Society Editorial Review Board Members and Authors' University Information January 1, 2007 - December 31, 2009

\begin{tabular}{|l|c|c|}
\hline & Home University & Doctoral-Granting \\
\hline of Editorial Review & University of Editoria \\
\hline
\end{tabular}

University of Alberta

University of California, Berkeley

Cardiff University

Case Western Reserve University

Columbia University

Copenhagen Business School

Cornell University

University of Edinburgh

Gothenburg University

Harvard University

IESE Business School

University of Illinois

Indiana University

University of lowa

University of Kansas

University of Lancaster

La Trobe University

London School of Economics

Maastricht University

University of Manchester

University of Melbourne

University of Michigan

Michigan State University

University of Minnesota

Monash University

Nanyang Technological University

Newcastle University

University of New Mexico

University of New South Wales

Nottingham University

Ohio State University

University of Pennsylvania

Pennsylvania State University

University of Pittsburgh

Preston Polytechnic

Queens University

Rice University

Rutgers University

University of St. Andrews

University of Sheffield

Stanford University

University of Southern California

University of Texas - Austin

Turku School of Economics

University of Warwick

University of Wisconsin - Madison

University of Wisconsin - Milwaukee

Yale University

York University

No Doctoral Degree

Other

Totals

\section{of Editorial Review University of Editorial}

Board Members

Review Board Members

Home University of Authors

\begin{tabular}{|c|c|c|}
\hline 1 & 0 & 8 \\
\hline 0 & 1 & 0 \\
\hline 2 & 0 & 11 \\
\hline 1 & 0 & 2 \\
\hline 0 & 1 & 0 \\
\hline 2 & 1 & 4 \\
\hline 2 & 2 & 0 \\
\hline 1 & 2 & 4 \\
\hline 1 & 0 & 0 \\
\hline 1 & 2 & 0 \\
\hline 1 & 0 & 1 \\
\hline 1 & 1 & 3 \\
\hline 2 & 0 & 3 \\
\hline 0 & 1 & 0 \\
\hline 0 & 1 & 0 \\
\hline 1 & 0 & 2 \\
\hline 0 & 1 & 0 \\
\hline 1 & 2 & 9 \\
\hline 1 & 0 & 0 \\
\hline 2 & 5 & 6 \\
\hline 1 & 0 & 0 \\
\hline 0 & 4 & 1 \\
\hline 1 & 0 & 1 \\
\hline 0 & 1 & 0 \\
\hline 1 & 1 & 4 \\
\hline 1 & 0 & 0 \\
\hline 0 & 2 & 1 \\
\hline 1 & 0 & 1 \\
\hline 2 & 1 & 4 \\
\hline 1 & 0 & 2 \\
\hline 0 & 2 & 0 \\
\hline 2 & 0 & 0 \\
\hline 1 & 1 & 0 \\
\hline 2 & 2 & 3 \\
\hline 0 & 1 & 0 \\
\hline 0 & 1 & 5 \\
\hline 1 & 0 & 2 \\
\hline 1 & 0 & 0 \\
\hline 1 & 0 & 0 \\
\hline 0 & 1 & 0 \\
\hline 2 & 1 & 1 \\
\hline 3 & 0 & 1 \\
\hline 0 & 1 & 1 \\
\hline 1 & 2 & 1 \\
\hline 2 & 2 & 5 \\
\hline 0 & 2 & 0 \\
\hline 1 & 0 & 1 \\
\hline 0 & 1 & 0 \\
\hline 2 & 0 & 5 \\
\hline 0 & 1 & 0 \\
\hline NA & NA & $\underline{152}$ \\
\hline$\overline{47}$ & $\overline{47}$ & $\overline{244}$ \\
\hline
\end{tabular}




\section{Journal of Accounting Research}

The results for the JAR are shown in Table 3. The authors' relationship with the editorial board members was less than with The Accounting Review. Less than $50 \%$ of the authors were at universities that had an affiliation with the members of the editorial review board. As shown in Table 1,29 articles were authored by editorial review board members. This is $28 \%$ of the total number of articles published. Authors were even more concentrated at selected universities than was the case at The Accounting Review. Nine universities accounted for over $48 \%$ of the total authors and coauthors. U.S. universities dominated the editorial board membership, with only four members being at foreign universities and three members possessing doctorates from foreign universities.

\section{Accounting Organizations and Society}

The results for AOS are shown in Table 4. The authors' affiliation with the editorial review board was less than at the other two journals. Only $38 \%$ of the authors were at universities with affiliations with the board members. Fewer articles were published by editorial review board members than at the other two journals. Twentynine articles or $23 \%$ of the articles published were published by board members during the three year period. The university concentration of authors was similar to $A R$. Eleven universities accounted for nearly $27 \%$ of the total authors. Since it's published in Great Britain, it would be expected the editorial board membership would be more international, and that was the case. Of the 47 board members, 25 members represented foreign universities and 22 were housed at U.S. Twenty-one board members possessed doctoral degrees from foreign universities.

\section{CONCLUSIONS}

The primary purpose of this article was to compare the university affiliations of the editorial review board members of three top accounting research journals and the university affiliations of the authors in these journals. As illustrated in the tables, over $50 \%$ of the authorship could be linked to universities where the board members had an affiliation. Secondarily it was also determined a small handful of universities dominated the membership of the review boards of AR and JAR. The AOS board tended to be more diverse with no university having more than three members on the board (University of Southern California) and only one U. S. university being the doctoral-degree granting university of more than two members (University of Michigan with four).

The journal editorial board membership of the two U.S. journals (AR \& JAR) was dominated by three universities; the University of Chicago, the University of Michigan and the University of Pennsylvania. These three universities accounted for 12 of the 101 members of the editorial review board of AR and 10 of the 36 members of the review board of JAR. This concentration is troubling given there are 596 AACSB accredited business programs (474 U.S. and 122 foreign) and 173 programs with specialized accounting accreditation (167 U.S. and 6 foreign) (AACSB International, 2010).

The 184 board members of the top three accounting research journals are represented by 65 of the 596 accredited business programs (51 U.S. and 14 foreign). Less than $11 \%$ of the accredited business programs were represented on the boards of these three journals. Of the 173 programs with specialized accounting accreditation, only 24 , or less than $14 \%$, were represented on the review boards of the AR, JAR and AOS. Given the large number of qualified business and accounting programs, there is an opportunity for editors to diversify this important task.

\section{AUTHOR INFORMATION}

Homer Bates has been a Professor of Accounting at the University of North Florida in Jacksonville for the past 26 years. He was previously on the faculty at the University of South Carolina in Columbia, and the University of Wisconsin-LaCrosse. He received his BS and MBA degrees from Indiana University and his Ph.D. from the University of Illinois. He is an Indiana CPA. His current teaching areas are financial and managerial accounting and his primary research interest is in accounting education. He has published in The CPA Journal, the Journal of Accountancy, Business Horizons, California Management Review, and other journals. 
Bobby Waldrup is Associate Dean and an Associate Professor of Accounting in the Coggin College of Business at the University of North Florida in Jacksonville, Florida. He has previously published in such journals as the CPA Journal, Strategic Finance, and the Journal of Information Systems. He is a Ph.D. and a CPA.

Vincent Shea is an Assistant Professor of Accounting at St John's University in Queens, NY. Prior to St John's, he was on the faculty at the University of North Florida. He received his BBA and MBA degrees from the University of North Florida and his Ph. D. from Kent State University. He is a Florida CPA. His current teaching areas are managerial accounting and accounting information systems. His primary research interest is in managerial accounting. He has published in the Journal of Information Systems, The CPA Journal, and other journals.

Whitney Heflin is a practicing CPA/CISA independent consultant. Prior to independent consulting, she served as the Director of Internal Audit for a SEC registered company. She has also served on the faculty at the University of North Florida where she taught managerial and accounting information systems courses as an adjunct. She received her BBA and MBA degrees from the University of North Florida.

\section{REFERENCES}

1. AACSB International website. (2010). www.aacsb.edu, last referenced on August 15, 2010.

2. Brinn, T., \& M. J. Jones. (2007). Editorial boards in accounting: The power and the glory. Accounting Forum, 31 (1):1-25.

3. Chan, K., Seow, G., \& Tam, K. (2009). Ranking accounting journals using dissertation citation analysis: A research note. Accounting, Organizations and Society, 34 (6/7): 875-885.

4. Chan, K., H.-G. Fung, \& P. Lai. (2004). Membership on Editorial Boards and Rankings of Schools with International Business Orientation. In GFCB Working Paper Series: Western Kentucky University.

5. Hammermesh, D. S. (1994). Facts and myths about refereeing. The Journal of Economic Perspectives, 8 (1): 153-163.

6. Hardin, W., K. Liano, K. Chan, \& R. Fok. (2008). Finance editorial board membership and research productivity. Review of Quantitative Finance \& Accounting, 31 (3):225-240.

7. Hasselback, J. R. (2007). Accounting Faculty Directory 2007, Upper Saddle River, NJ: Prentice-Hall.

8. Jönsson, S. (2006). On academic writing. European Business Review, 18 (6): 479-490.

9. Lee, T.A. (1997). The editorial gatekeepers of the accounting academy. Accounting, Auditing \& Accountability Journal, 10 (1): 11-30.

10. Mittermaier, L. J. (1991). Representation in the editorial boards of academic accounting journals: an analysis of accounting faculties and doctoral programs, Issues in Accounting Education, 6 (2): 221-38.

11. Moizer, P. (2009). Publishing in accounting journals: A fair game? Accounting, Organizations \& Society, 34 (2):285-304.

12. Nisonger, T. E. (2002).The relationship between international editorial board composition and citation measures in political science, business, and genetics journals. Scientometrics, 54 (2): 257-268.

13. Swanson, E.P. (2004). Publishing in the majors: A comparison of accounting, finance, management and marketing. Contemporary Accounting Research, 21 (1): 119-121.

14. Weinrach, S., K. Thomas, S. Pruett, \& F. Chan. (2006). Scholarly Productivity of Editorial Board Members of Three American Counseling and Counseling Psychology Journals International Journal for the Advancement of Counselling, 28 (3):303-315.

15. Williams, P. F., \& J. L. Rodgers. (1995). The Accounting Review and the Production of Accounting Knowledge. Critical Perspectives on Accounting, 6 (3):263-287. 